UDK 334.723

DOI: 10.54649/2077-9860-2021-1-56-68

Shaimerden Chikanayev ${ }^{1^{*}}$

${ }^{1}$ LL.M., GRATA International Law Firm, Republic of Kazakhstan, Almaty

E-mail: schikanayev@gratanet.com

\title{
PUBLIC-PRIVATE PARTNERSHIPS IN KAZAKHSTAN: EVOLUTION OF THE GOVERNMENT POLICY AND REALITY OF PPP DEPLOYMENT
}

\footnotetext{
PART $1 I^{3 * * *}$

This article examines PPP development in Kazakhstan from 1991 to the time of writing. Article reviews evolution of the PPP legislation and approaches used to develop a PPP-enabling environment in

* S. Chikanayev (B ).GRATA International Law Firm, Almaty, Kazakhstan. Shaimerden Chikanayev is an advocate of the Almaty City Bar and a partner of GRATA International Law Firm, Almaty, Kazakhstan. He has over 13 years of experience in Kazakhstan's legal services market, and significant experience in matters relating to countries of Central Asia. His practice focuses on a wide range of finance and mergers and acquisitions transactions. Shaimerden has extensive knowledge of various industries, and in particular energy, utilities and social infrastructure, financial services, and transportation.

** This article is based on materials published in: Kazakhstan's Developmental Journey. Entrenched Paradigms, Achievements, and the Challenge of Global Competitiveness/ Edited by Anastasia Koulouri\&Nikolai Mouraviev/ S. Chikanayev Ch. 6. Public-Private Partnerships in Kazakhstan: Evolution of the Government Policy and Reality of PPP Deployment /ISBN 978-98115-6898-5 ISBN 978-981-15-6899-2 (eBook) https://doi.org/10.1007/978-981-15-6899-2 @ The Editor(s) (if applicable) and The Author(s), under exclusive license to Springer. Nature Singapore Pte Ltd. 2021. P. 153-180.

*** For the convenience of readers, the article was divided into two parts by the decision of the editorial board. Part 1 was published in the previous issue of the journal
} 
order to draw lessons for the country's future policy. This article describes evolution of the PPP concept in the country and provides analysis of gaps and deficiencies in the current PPP policy and legislation.

The PPP definition and the scope of PPP activity has evolved significantly in the nation's legislation and legal literature since 1991. Author distinguish the following five stages of the PPP development in Kazakhstan: Stage One-PPP legal framework for foreign investors only (1991-1993); Stage Two-Lack of PPP-specific legal framework and "pilot" projects (1994-2005); Stage Three-The formation of legal and institutional frameworks (2006-2015); Stage Four-Active PPP deployment: the focus being on quantity (2016-2018); Stage Five-Adjustments to the PPP framework: stricter requirements (2019present).

In this article, the author examines the last three stages from 2006 to present, paying attention to the actions of the government, Policy Goals at the Stage Three. Stage Four and Stage Five, assessing the implications for further policy development of public-private partnerships in the state. the author examines that despite forming advanced legal and institutional PPP frameworks and promulgating a policy document (the PPP Programme), there was an apparent lack of success in PPP implementation during Stage Three. It seems that the country lacked the critical element that is required for successful PPP implementation: high-level political support that would overcome all kinds of resistance to private sector involvement in public service delivery. During Stage Four, there was also a rapid increase in the execution of different agreements that were called PPP agreements but. author considers that strictly speaking, should not be treated as such, as they are just imitations of a PPP. By the end of Stage Four, therefore, all relevant stakeholders expected the government to roll out changes in the PPP policy and legal and institutional frameworks to curb the growing government debt risk and prevent the misuse of fiscal funds by the regional and local authorities. On Stage Five Kazakhstan's government announced a new PPP policy with project quality as a priority. But nowadays as the coronavirus outbreak spreads across the globe, it is likely that many existing PPP projects in Kazakhstan will experience considerable revenue generation challenges.

Key words: public-private partnership, politics, government, investor, investment, economy, infrastructure, concession, contracts, agreements.

\author{
Ш.А. Чиканаев ${ }^{1}$ \\ 1 3.f.M., GRATA халықаралық заң фирмасы, \\ Қазақстан Республикасы, Алматы қ. \\ E-mail: schikanayev@gratanet.com
}

\title{
ҚАЗАҚСТАНДАҒЫ МЕМЛЕКЕТТІК-ЖЕКЕМЕНШІК СЕРІКТЕСТІК: МЕМЛЕКЕТТІК САЯСАТЫНЫҢ ЭВОЛЮЦИЯСЫ ЖӘНЕ МЖӘ ОРНАТУДЫҢ ШЫНДЫҒЫ. ІІ БөлІм
}

\begin{abstract}
Аңдатпа
Бұл мақалада Қазақстандағы МЖӘ-нің 1991 жылдан бастап мақала жазылған сәтке дейінгі дамуы зерттелінген. Онда МЖӘ туралы заңнамасының эволюциясы және елдің болашақ саясатына сабақ алу үшін МЖӘ үшін қолайлы жағдай жасау тәсілдері қарастырылды. Бұл мақалада елдегі МжӘ тұжырымдамасының эволюциясы сипатталады және МЖӘ аясындағы қолданыстағы саясатындағы және заңнамасындағы олқылықтар мен кемшіліктер талданады.

МЖӘ анықтамасы және МЖӘ қолдану аясы 1991 жылдан бастап ұлттық заңнамада және заң әдебиеттерінде айтарлықтай өзгеріске ұшырады. Автор Қазақстандағы МжӘ дамуының келесі бес кезеңін бөліп көрсетеді: Бірінші кезең - бұл тек шетелдік инвесторларға арналған МжӘ-нің құқықтық негіздері (1991-1993 жж.); Екінші кезең - Мжә және «пилоттық» жобалар үшін нормативтік-құқықтық базаның жоқтығы (1994-2005); Үшінші кезең - құқықтық және институционалдық базаны қалыптастыру (2006-2015 жж.); 4 кезең - Белсенді МжӘ қолдану: санға негізінен назар аударылады (2016-2018); Бесінші кезең - МЖә құрылымын түзету: неғұрлым қатаң талаптар қойылады (2019 жылдан бастап қазіргі уақытқа дейін).

Бұл мақалада автор үкіметтің іс-әрекеттеріне, қарастырылып отырған жекелеген кезеңдердегі саяси мақсаттарға назар аудара отырып, мемлекеттегі мемлекеттік-жекеменшік серіктестікті дамытудағы саясаттың салдарын бағалай отырып, 2006 жылдан бастап қазіргі
\end{abstract}


уақытқа дейінгі қалған үш кезеңді қарастырады. Ол Мжә-нің жетілдірілген заңнамалық және институционалдық базасы қалыптасқанына және стратегиялық құжаттың (МЖә бағдарламасы) жарияланғанына қарамастан, МЖә жүзеге асырудың үшінші кезеңі табысқа жете алмағандығы жайлы қорытындыға келеді. Елде МЖӘ сәтті жүзеге асырудың маңызды элементі - мемлекеттік қызмет көрсетуге жеке сектордың қатысуына қарсы тұрудың барлық түрлерін жеңетін жоғары деңгейдегі саяси қолдау жетіспейтін сияқты болды. Төртінші кезең барысында Мжә келісімдері деп аталатын әртүрлі келісімдердің орындалуының қарқынды өсуі байқалды, бірақ автор айтуынша шын тұрғыдан оларға МЖӘ-нің имитациясы ретінде қарастыруға болады деп санайды. Төртінші кезеңнің соңында, демек, барлық мүдделі тараптар үкіметтен МЖә саясатына және өсіп келе жатқан мемлекеттік қарыздар тәуекелін болдырмау және аймақтық және жергілікті органдардың бюджеттік қаражатты мақсатсыз пайдалануына жол бермеу үшін құқықтық және институционалдық негіздерге өзгерістер енгізеді деп күтті. Бесінші кезеңде Қазақстан үкіметі жобаның сапасына басымдық берілген жаңа МЖӘ саясатын жариялады. Алайда, қазіргі уақытта коронавирустық эпидемия бүкіл әлемге таралатындықтан, Қазақстандағы көптеген МЖә жобалары кірістер бойынша айтарлықтай қиындықтарға тап болуы мүмкін.

Түйінді сөздер: мемлекеттік-жекеменшік серіктестік, саясат, үкімет, инвестор, инвестиция, экономика, инфрақұрылым, концессия, келісімшарттар, келісімдер.

\author{
Ш.А.Чиканаев ${ }^{1}$ \\ ${ }^{1}$ м.ю.н., Международная юридическая фирма GRATA, \\ Республика Казахстан, г. Алматы \\ E-mail: schikanayev@gratanet.com
}

\title{
ГОСУДАРСТВЕННО-ЧАСТНОЕ ПАРТНЕРСТВО В КАЗАХСТАНЕ: ЭВОЛЮЦИЯ ГОСУДАРСТВЕННОЙ ПОЛИТИКИ И РЕАЛЬНОСТЬ РАЗВЕРТЫВАНИЯ ГЧП.
}

\section{ЧАСТЬ II}

\begin{abstract}
Аннотация
В данной статье исследуется развитие ГЧП в Казахстане с 1991 года до момента написания статьи. Рассматривается эволюция законодательства о ГЧП и подходы, используемые для создания благоприятной среды для ГЧП в целях извлечения уроки для будущей политики страны. В данной статье описывается эволюция концепции ГЧП в стране и проводится анализ пробелов и недостатков в действующей политике и законодательстве в области ГЧП.

Определение ГЧП и сфера деятельности ГЧП претерпели значительные изменения в национальном законодательстве и юридической литературе с 1991 года. Автор выделяет следующие пять этапов развития ГЧП в Казахстане: Первый этап- правовая база ГЧП только для иностранных инвесторов (1991-1993 гг.); Второй этап - отсутствие нормативно-правовой базы по ГЧП и «пилотных» проектов (1994-2005 гг.); Третий этап - формирование правовой и институциональной базы (2006-2015 гг.); Четвертый этап - развертывание активного ГЧП: основное внимание уделяется количеству (2016-2018 гг.); Пятый этап - корректировка структуры ГчП: более строгие требования (с 2019 г. по настоящее время).

В данной статье автор рассматривает оставшиеся три этапа с 2006 года по настоящее время, уделяя внимание действиям правительства, политическим целям на отдельных рассматриваемых этапах, давая оценку последствия для проведения дальнейшей политики в сфере развития государственно-частного партнерства в государстве. Им делается вывод, что несмотря на формирование передовых правовых и институциональных рамок ГЧП и обнародование стратегического документа (Программа ГЧП), на третьем этапе реализации ГЧП явно не удавалось добиться успеха. Похоже, что стране не хватало критически важного элемента, необходимого для успешной реализации ГЧП: политической поддержки на высоком уровне, которая преодолела бы все виды сопротивления участию частного сектора в предоставлении государственных услуг. На четвертом этапе также наблюдалось быстрое увеличение количества заключенных соглашений, которые назывались соглашениями о ГЧП, но, строго говоря, автором отмечается, что их не следует рассматривать как таковые, поскольку они представляют собой всего лишь имитацию ГЧП. Таким
\end{abstract}


образом, к концу четвертого этапа все соответствующие заинтересованные стороны ожидали, что правительство внесет изменения в политику ГЧП, а также в правовую и институциональную базу, чтобы ограничить растущий риск государственного долга и предотвратить нецелевое использование бюджетных средств региональными и местными властями. На пятом этапе правительство Казахстана объявило о новой политике ГЧП с приоритетом качества проектов. Однако в настоящее время по мере того как эпидемия коронавируса распространяется по всему миру, вполне вероятно, что многие существующие проекты ГЧП в Казахстане столкнутся со значительными проблемами с получением доходов.

Ключевые слова: государственно-частное партнерство, политика, правительство, инвестор, инвестиции, экономика, инфраструктура, концессия, контракты, соглашения.

\section{Stage Three-the Formation of Legal and Institutional Frame works (2006-2015)}

\section{What Was Done}

Although Kazakhstan received some experience of PPP-based projects during stages one and two, successful deployment of new partnership projects would not be effective without comprehensive statutory legislative package on PPP procurement. During Stage Three, Kazakhstan managed to put in place well-structured legal and institutional frameworks for launching PPPs at both the national and regional levels (European Bank for Reconstruction and Development (EBRD) [1]; Rivadeneira and Garin [2]) .

In 2006, the new Concession Law was adopted, which already in 2007 enabled execution of the now specifically recognised concessions (i.e. a concession agreement now became a nominate contract from Kazakhstan's civil law perspective). These were concession agreements on construction and operation of the passenger terminal of the International Airport in the city of Aktau; the Yeraliyevo-Kuryk railway line (construction and operation); and electrification of the MakatKandyagash railway line. This was followed by execution in 2008 of the concession agreements on construction and operation of the gas turbine plant in the city of Kandyagash (in Aktobe region) and the railway line Korgas-Zhetygen (Mouraviev et al. [3]) . However, the then largest PPP project that was expected to pave the way for more partnerships with foreign investors and lenders was the Big Almaty Ring Motor Road concession project (a toll road around Almaty), also known as BAKAD. The Ministry of Industry and Infrastructure Development with assistance of the International Finance Corporation as its advisor put the BAKAD project out to tender under the Concession Law framework at the beginning of 2015, although this long-delayed project was first conceived as early as 2008. The BAKAD 20-year, build-transfer-operate (BTO) concession agreement has been signed in February 2018 by a con- sortium (comprising South Korea's SK E\&C, Korea Expressway Corp and Turkey's Alarko and Makyol) acting as a concessionaire. The project offers an enticing risk/reward combination. While construction cost amounts to USD 540 million, the total project cost is estimated at USD 750 million. While Kazakhstan's government agreed to assume all traffic risk, toll revenue will be collected by the concessionaire and transferred to the government straight away. In turn, the government will be making a front-loaded availability payment to cover investors' capital expenditure, plus will be paying interest during the first 10 years of operation to mimic the debt repayment schedule. At the same time, the investors' operating expenses, replacement capital expenditure, taxes, cost of capital and other costs will be covered throughout the whole operation period, to the end of the project. The government will also mitigate currency fluctuation risk and compensate for any depreciation of tenge (Kazakhstan's national currency) against the US dollar above 5\%. Even though the BAKAD concession agreement was signed back in February 2018, it took another two years to reach financial close when all relevant stakeholders, including EBRD, managed finally to agree, in February 2020, on project financing (Newsworld [4]) . There is high expectation for success of this project because if BAKAD will not be implemented for any reason, foreign investors, lenders and international financial institutions (IFIs), that so far supported Kazakhstan's government PPP initiatives, may lose trust in government's commitment to engage foreign partners in any PPPs.

Importantly, as of April 2020, out of all above-mentioned concessions only one has been working successfully (i.e. a facility has been constructed and is already functioning)the passenger terminal of the Aktau airport. It means that the law on concessions is in effect already for 14 years, although only one concession project has been successful under its legal framework (Kazakhstan Public-Private Partnership Centre [5]) . 
Concessions lack popularity partly owing to excessive regulation by the relevant legislation and because the process for granting a concession in Kazakhstan is bureaucratic and time-consuming. To address this issue, the government throughout Stage Three tried to improve the Concession Law by introducing numerous changes. For example, upon its adoption in 2006 the law allowed concessions to be structured only as either BTO or design-build-transfer-operate (DBTO) projects (i.e. upon completion of the construction phase, ownership of the relevant concession facilities was required to be transferred to the government). This statutory limitation proved to be an unnecessary obstacle for concession projects, and investors often required greater flexibility. The Concession Law, therefore, later has been amended to allow all possible PPP models. Nowadays, a concession agreement may include an option for a private partner to keep ownership of the concession facility upon project completion. Currently, all available PPP schemes may be structured.

In addition to the Concession Law, Kazakhstan also adopted the Project Finance Law in 2012 when the project finance concept was introduced into national legislation. There is now a solid basis for the structuring of PPP schemes on the principles of project finance. So far, however, project finance in the strict sense of the term (i.e. where financing is based on the performance of the project itself) under the Project Finance Law has not yet been tested in Kazakhstan.

In addition to the legal framework, during Stage Three, the government managed to form quite a sophisticated institutional framework for PPPs (Rivadeneira and Garin [2]) . For the national-level concession projects in their sector (e.g. the Ministry of Healthcare for hospital projects), the line ministries perform the role of a contracting authority (de facto on behalf of the Republic of Kazakhstan). The line ministries decide on the delivery mode for investment projects and develop documentation for PPPs. Local governing bodies (akimats) perform the role of a contracting authority (de facto on behalf of a respective region or a city) for all local-level concession projects. The state body that is procuring the PPP (i.e. a contracting authority) is the institution ultimately responsible for the project. The contracting authority is responsible for the preparation, negotiation, and administration of the contract, and for monitoring and evaluating contract performance during the construction and operation phases of the project. This authority, therefore, carries the ultimate responsibility for the PPP contract and its implementation (Rivadeneira and Garin [2]) .

In 2008, Kazakhstan established its specialised unit called Kazakhstan Centre for Public-Private Partnership (the PPP Centre) located in the nation's then capital city, Astana, (renamed NurSultan in 2019) to facilitate PPP projects. The centre is charged with the economic evaluation of proposed PPPs, including concessions and assistance with project preparation, such as evaluation of tender documentation, bids of potential private partners, and drafts of the concession/ PPP agreements. Later, in 2014, the PPP Centre set up the Kazakhstan Project Preparation Fund LLP (KPPF) as a joint venture with the National Management Holding Baiterek which is an organisation managing a large number of the country's companies. The KPPF promotes infrastructure development in Kazakhstan through providing services for structuring and supporting infrastructure projects including those that make use of the PPP model. The KPPF can assist with drafting tender documentation, a concession or a PPP agreement. It also could be involved in negotiating with potential investors and concessionaries, as well as working with the government organisations regarding securing approval for the project documentation. The KPPF, in general, serves as an external independent adviser to the national government and sometimes to the local authorities. Finally, nowadays, almost every region (ob la st) in Kazakhstan has its own PPP Centre responsible for the development of PPP in a respective region. Furthermore, a few line ministries in Kazakhstan have created their own units (departments) for developing PPP projects (Rivadeneira and Garin [2]) .

Kazakhstan also managed to build up a diverse pool of different types of lenders that could finance PPP projects. Firstly, it is the Development Bank of Kazakhstan, a government-owned entity responsible for financing infrastructure projects including PPPs. Secondly, domestic commercial banks could be interested in financing PPPs and there are already small-scale projects financed by the commercial banks, despite lacking appetite and capacity to engage with large projects. Finally, most of the national-level PPP projects so far relied on IFIs. IFIs strongly support PPP development and their assistance to Kazakhstan's government is not limited to lending, but also includes rendering international expertise in managing PPPs. The Asian Development Bank (ADB), the EBRD and the International Finance Corporation (IFC) are espe- 
cially active in Kazakhstan. Quite often they help the government by serving as advisors regarding PPP structuring or by bringing in international and local consultants in order to improve PPP-related legislation.

As for the PPP policy in Kazakhstan, it is mainly led by the Ministry of National Economy as an authorised state body that is assisted by the PPP Centre. The ministry sets the guidelines, drafts PPP legislation and has an overarching monitoring role with regards to PPPs. In addition, the Ministry of Finance, sectoral ministries, the local authorities and the National Chamber of Entrepreneurs (Atameken) also play an important role in the development of the PPP policy in the country.

\section{Policy Goals at This Stage}

In 2010, the government launched the Programme for Accelerated Industrial-Innovative Development of Kazakhstan in 2010-2014 (the Industrialisation Programme). It envisaged the implementation of at least 15 PPP projects per year totalling over KZT 900 billion (about USD 6 billion) by 2015. In furtherance of the Industrialisation Programme, in 2011 the government approved the Programme for Development of Public-Private Partnership in 2011-2015 (the PPP Programme). The expectation was that simultaneously the Ministry of Economic Development and Trade would facilitate the creation of an appropriate legislative and regulatory framework for implementation of infrastructure projects using PPP mechanism. Stage Three in the PPP development was, therefore, the first time when a national PPP policy document (the PPP Programme) was promulgated. Its major goal was to create specific legislative and institutional frameworks for PPPs. This goal has been successfully accomplished (as discussed above in the section What was done [Stage Three]). The government, however, fell short of achieving another goal set in the PPP Programme, namely to implement twice as many PPP projects by 2015 as compared to 2008 . In reality, no projects have been implemented during this time, although a few concession projects, including BAKAD, have been announced during Stage Three.

The PPP Programme declared education, healthcare, toll roads, and housing and public utilities as priority sectors for PPPs. However, it seems that in fact the major goal during Stage Three was to attract foreign investment and implement about ten large-scale PPP projects, with a total value of more than USD 4 billion, in the transportation sector and, therefore, create the PPP projects that would serve as a benchmark (Matayev [6]) .

To summarise, the PPP Programme as de facto national PPP policy proved to be an effective tool for PPP development as the government set clear objectives and targets and established the priority sectors for partnerships. This matched the expectation of foreign investors and other interested parties. Unfortunately, the practice of promulgation of similar national PPP policy documents did not continue after the PPP Programme had ended in 2015. It is not surprising, therefore, that the Asian Development Bank's PPP Monitor notes a lack of formal, published PPP guidelines and the list of projects in the pipeline as one of the impediments to PPP development in Kazakhstan (ADB [7]) .

\section{Assessment}

During Stage Three of PPP development, the understanding of a PPP was narrowed to simply mean a concession (Mouraviev and Kakabadse [8]) . In the 2006 Law on Concessions, a concession is defined as activity aimed at construction (or renovation) and operation of a facility, performed at the expense of a concessionaire or with co-financing by the grantor. The legislation, therefore, allows the public sector partner to provide additional forms of support to a concessionaire. The government can (and often does) provide financial support to a project, although the legislation limits this support to the total value of the completed project. The concession law includes the concepts of an availability payment to ensure continuous operation of a concession facility and state subsidies as both an additional source of income for a concessionaire and a tool to reimburse its expenses. The availability payment includes outlays from the government budget as compensation of concessionaire's certain investment and operational expenses and, if applicable, any service fees for trust management of the government-owned property (i.e. a concession facility) or lease payment paid by the government for the use of a concession facility owned by a concessionaire. Importantly, the Concession Law provides possibility to obtain an availability payment only for concession projects that have been categorised as "socially important", such as kindergartens. The Kazakhstan's definition of a concession, therefore, is different from traditional understanding of a concession in Western Europe and international legal literature (UNECE PPP As- 
sessment Report [9]) . In the traditional concept, a concession is limited to a special type of a PPP in which a private sector entity is allowed only to charge the general public for using the concession facility ("users pay" model) but is not able to claim any compensation from the state budget (Yescombe and Farquharson [10]) .

Unlike the 1991 concession law that categorised a concession agreement as an administrative contract, the 2006 Concession Law classifies a concession agreement as a special type of a private law contract. It means that any concession agreement is a nominate contract that must have the following two elements as a subject matter: (i) creation/reconstruction of a concession facility and (ii) operation of this facility in accordance with its designated use. For instance, if the concession facility is a school, a concessionaire must deliver the core service by providing educational services (i.e. a "limited service" project under which the services provided by the private partner during the operations phase do not include educational services, but are limited to facility maintenance and management, cannot be structured under concession agreement). Another practical implication of categorising a concession agreement as a nominate contract is that it has its own specific regulation that is different from non-concession PPP agreements. For example, Kazakhstan's Tax Code provides specific/preferred tax regulation only for the concession agreements and not for any other types of PPP agreements.

Importantly, a concession facility can only be a property that may be recognised as the so-called social and vital infrastructure facility (i.e. a facility used for meeting the public needs, the securing of which is imposed on state authorities by Kazakhstan's law). The Concession Law, therefore, cannot be used for the construction of, for example, a fertiliser plant as it is unlikely to be considered a facility used for meeting public needs, the securing of which is imposed on state authorities. Unlike the Russian concession legislation, Kazakhstan's Concession Law does not provide an exhaustive list of the property types that could be objects of a concession agreement. However, in general, only immovable and movable property may be a concession facility in Kazakhstan (Tuktarov and Dubinchina [11]) .

It is worth noting that there were two drafts of the concession law submitted for consideration of the Parliament in 2006. One draft was prepared by the Ministry of the National Economy and the other draft was prepared by civil law scholars led by renowned academic Professor MK Suleimenov.
Although the law is a blend of the two drafts, unfortunately, the final version was mainly based on what the ministry proposed (Beisembinova [12]) . This explains the gaps and ambiguous provisions that still exist in the concession law. For example, one of the major reasons why it took more than two years to reach a financial close with the lenders of the BAKAD project was confusion regarding who was the concession grantor. The 2006 concession law states that only authorised state bodies (e.g. the Ministry of Industry and Infrastructural Development, which signed the BAKAD concession agreement) can act as a concession grantor and enter into concession agreements, but this contradicts Kazakhstan's legislation because state bodies are not subjects of civil law and, therefore, they do not have any assets and cannot enter into any civil law agreements on their own behalf (i.e. strictly speaking state bodies can act and sign a concession agreement on behalf of the public law entities, e.g. the Republic of Kazakhstan or its region or a city, but not on their own behalf as legal entities). From the bankability perspective, it makes significant difference if the grantor is the Republic of Kazakhstan that has many assets, or just a ministry with effectively no assets at all to meet its contractual obligations.

\section{Implications for Further Policy Development}

At Stage Three, the principal learning point is that developing a policy document and setting legal and institutional frameworks are not enough for creating a PPP-enabling environment. Despite forming advanced legal and institutional PPP frameworks and promulgating a policy document (the PPP Programme), there was an apparent lack of success in PPP implementation during Stage Three. It seems that the country lacked the critical element that is required for successful PPP implementation: high-level political support that would overcome all kinds of resistance to private sector involvement in public service delivery. Many officials (in the line ministries and regional and local governments) at that stage did not see powerful incentives for their respective organisations to embark upon PPP implementation that back then was a novel, quite complicated and time-consuming mechanism compared to the traditional public procurement process. There is no surprise, therefore, that during Stage Three only one concession project (the passenger terminal of the international airport in Aktau) has been successful.

Stage Four - Active PPP Deployment : The Focus Being on Quantity (2016-2018) 


\section{What Was Done}

The end of year 2015 became extremely fruitful in terms of making changes to the PPP legislation as the new piece of legislation-the PPP Law-and all necessary by-laws have been adopted (Law on Public private Partnership [13]) . Importantly, Kazakhstan's president in his address to the nation on 30 November 2015 specifically urged the use of PPP for economic development, which provided a powerful impetus to all officials and extended much-needed high-level political support for PPP implementation. Having established a solid legal and institutional basis for the PPP projects and a clear message from the president to implement PPPs in all sectors of the economy, at the end of 2015 the national government officially confirmed that from then on each region in Kazakhstan would have to meet a new target: to implement at least five PPP projects per year. The government has also set similar targets for the number of PPP agreements that line ministries must sign on an annual basis. It also instructed line ministries and regional authorities to develop a road map by March 2016 for PPP formation in their respective sectors and regions with the specific target indicators.

As a result, soon thereafter two contracts have been signed under the framework of the new PPP Law. These were the national-level PPP projects: a contract to build a checkpoint and a transport and logistics centre in the international transit corridor, "Western Europe - Western China", and a contract to design and operate an automated information system, "Kandelik" (Rivadeneira and Garin [14]) . The checkpoint and a transport and logistics centre project were executed as a PPP agreement in 2017 without a public tender as a result of so-called direct negotiations with a domestic investor-LLC Eurotransit Terminal-and was financed by the Eurasian Development Bank. This was the first nationallevel PPP agreement and the only arrangement that had two public sector partners (two ministries) as counterparties of the agreement. The interpretation of the law, however, suggests that de facto there is only one public partner: the Republic of Kazakhstan represented by its two state bodies (ministries).

However, the regional level, rather than the national level, saw a rapid increase of the number of executed PPP agreements during Stage Four. At this stage, half of the projects have a maximum investment not exceeding KZT 100 million (about EUR 250,000). Furthermore, $80 \%$ of the projects have a total value below KZT 500 million (EUR
1.25 million) (Rivadeneira and Garin [14]) . Poor PPP project selection and preparation by the local authorities (mainly owing to a lack of competence in the regions and/or lack of relevant officials that were ready to take on the responsibility of making the necessary decisions) inevitably resulted in defaults, litigations, and the invalidation of many inadequately structured PPP agreements (some of which did not comply with the PPP legislation) and tenders during Stage Four (SZP [15]) .

Still, the largest project at the local level is the Almaty Light Rail Transit (LRT) PPP, although there is confusion regarding who a public sector partner might be and against what assets the private sector partner might have legal recourse. Systematic interpretation of the 2015 PPP Law suggests it is the city of Almaty (rather than the Republic of Kazakhstan) and, therefore, a future private partner of the Almaty LRT project may have legal recourse only against the municipal budget of Almaty, but not the state budget of Kazakhstan. The city government is prepared to give a subsidy to cover $50 \%$ of the capital cost and retain ridership, but the city expects to receive all ticket revenue. The private sector partner would be paid an availability payment to cover its investment and operating costs. The Almaty LRT PPP project is also a good example of the public sector partner unexpectedly changing its mind in the middle of the tender process. Although four international consortia successfully passed the first stage of the open tender and in 2019 entered the second stage, the newly appointed mayor of Almaty currently proposes two options: (1) to abandon a PPP model for a light rail and instead build and operate the LRT system by the public sector organisations as, presumably, this option offers better value for money or (2) to abandon the project altogether. It is likely that a change of plans is triggered by doubts of whether it is feasible to attract private investors without very high costs or the central government guarantees for potential liabilities. Furthermore, implementing the project via public sector organisations, rather than the private firms, could save hundreds of millions of dollars.

\section{Policy Goals at This Stage}

During Stage Four, the government pursued two goals in furtherance of its new PPP policy developed by the Ministry of the National Economy in collaboration with the PPP Centre. The first goal was to establish a new legal framework under the PPP Law that should have provided for much broader understanding of the PPP concept. 
A new framework was expected to be more flexible compared to the one formed under the 2006 concession law (i.e. the new PPP Law did not intend to replace the Concession Law; rather, it aimed at providing a more flexible and robust solution for PPPs) (Rivadeneira and Garin [14]). The second goal was to implement many small-scale and simple (service-type) PPP projects under the PPP Law at the regional level, rather than just a few large-scale infrastructure projects at the national level under the Concession Law, as was the case of the PPP policy during Stage Three. To meet these goals, the government pushed for decentralised PPP preparation, approval, and implementation, so that the regional and local authorities would have more power and could implement the regional-level PPP projects faster, without a need to get any approvals from the PPP Centre or the national ministries. Supported by the PPP Law, the new policy has led to a sharp increase in PPP formation at the regional level, with 15 PPP agreements signed in 2016, 166 in 2017, and 304 in 2018 (Atameken [16]). These regional projects have been focused on the social infrastructure, including kindergartens and primary schools (54\% of the total number of executed PPP agreements), primary healthcare centres (21\%), and sports and recreation facilities, such as halls for martial arts (14\%). Many of the projects developed under the PPP Law during this stage took the form of service contracts, such as street cleaning or waste processing, with limited capital investment (Rivadeneira and Garin [14]) .

\section{Assessment}

The PPP Law significantly broadened the PPP concept by viewing a partnership as a form of cooperation between the public partner and a private partner that corresponds to the features defined by the law. These features include (i) relations between the public and private sector partners in the form of a PPP agreement, (ii) medium-term or long-term PPP project implementation (from 3 to 30 years), (iii) joint participation of the public and private sector partners in project implementation, and (iv) resource sharing by the partners to facilitate project implementation. A very broad definition of a PPP enables the launch of projects in any sector of the economy. Therefore, PPP facilities under the 2015 PPP Law, unlike the 2006 concession law, do not necessarily have to be used for satisfying the public needs, the securing of which is imposed on state authorities (e.g. the construction of a fertiliser plant or sub- soil utilisation project are now eligible for implementation under the PPP Law).

The law enlists possible types of a PPP agreement, including a concession agreement, trust management of state-owned property agreement, and a life cycle contract; however, the list remains open, so it is possible to enter into other agreements that align with the PPP features. Logical and systematic interpretation of the PPP Law, however, suggests that in fact under the current law there are only two types of a PPP agreement: a concession agreement and a non-concession agreement.

- A concession agreement (for the purposes of the civil law) is a socalled nominate contract with its own specific legislation and even tax regulation. This means that a concession agreement should not be considered a type of a PPP agreement and, therefore, should not be subject to regulation by the PPP Law.

- A non-concession PPP agreement (for the purposes of the civil law) is a so-called mixed contract (i.e. a contract that contains the elements of different types of a contract provided by the law). A non-concession agreement also has its own special legislation and features.

This means that Kazakhstan's PPPs in effect have two forms: (1) a concession and (2) a nonconcession PPP, which both have different legal frameworks.

The subject of a PPP agreement in the form of a mixed contract is not clearly defined by the PPP Law because it can vary depending on the types of contract a particular PPP agreement consists of. However, in general, it can be related to any type of activities including construction and/or developing infrastructure and/or rendering services. Furthermore, a PPP agreement is not only a mixed contract, but also a nominate contract, which means that a PPP agreement should be considered concluded only when relevant parties agree on all essential terms of the PPP agreement as stipulated in the PPP Law (Chikanayev [17]) .

Most academics and businesspeople view a PPP as a contractual agreement (Mouraviev and Kakabadse [8]) . However, a PPP acquired specific legal meaning under Kazakhstan's law during Stage Four and, therefore, the PPP concept in Kazakhstan nowadays covers only two specific contractual arrangements: (1) a concession agreement and (2) a PPP agreement. A wide variety of other contractual arrangements involving the public and private sector partners (e.g. trust management of state-owned property agreement ex- 
ecuted under the State Property Law), executed not in accordance with either the 2015 PPP Law or the 2006 Concession Law, therefore, cannot be qualified as a PPP.

Legislation also failed to make clear how these two laws are linked and what distinctive features of the concession law make it, in certain cases, a preferred option when compared to the PPP Law. Nevertheless, the PPP Law currently has a number of provisions that are either unclear (and the approach to the application thereof must first be tested in courts) or too onerous to the business (Chikanayev [18]) . This is why for the time being the concession model remains the most popular option for IFIs and foreign investors in Kazakhstan.

\section{Implications for Further Policy Development}

The evidence suggests that many local (city) and regional authorities have been improperly using the PPP concept during Stage Four in order to attract private investors or as a cover for irregular procurement practices or public borrowing. For example, under the PPP Law, a private sector partner may be selected through so-called direct negotiations (i.e. without an open tender) in certain cases as stipulated in the law. The problem is that, in practice, the direct negotiations method might be misused by the regional and local governments and affiliated business entities as a loophole that allows awarding a contract without competition. The fact that more than $50 \%$ of the PPP agreements executed by the end of 2018 were procured through direct negotiations (i.e. without an open tender) raises serious concerns. During Stage Four, there was also a rapid increase in the execution of different agreements that were called PPP agreements but, strictly speaking, should not be treated as such, as they are just imitations of a PPP (i.e. these agreements often do not correspond to the features and principles of the PPP as prescribed by the PPP Law and discussed in the Assessment section above) and should be requalified as public procurement contracts. This has caused confusion and uncertainty regarding PPPs, which was driven mainly by the swiftly formed negative perception of how PPPs develop in Kazakhstan. By the end of Stage Four, therefore, all relevant stakeholders expected the government to roll out changes in the PPP policy and legal and institutional frameworks to curb the growing government debt risk and prevent the misuse of fiscal funds by the regional and local authorities.
Stage 5-Adjustments to the PPP Framework: Stricter Requirements (2019-Present)

\section{What Was Done}

As the national-level PPP and concession projects in Kazakhstan were put under the microscope of many controlling state entities, including the PPP Centre, in an attempt to have a truly competitive and transparent PPP selection process, the regional- and local-level PPP projects benefited from more relaxed oversight. As the Organisation for Economic Co-operation and Development (OECD) rightfully noted in its report, the PPP preparation capacity is concentrated at the central level, although most of the activity takes place at the regional level, where there is much less capacity and expertise (Rivadeneira and Garin [14]) . The PPP projects, therefore, created in the regions a commonly shared perception that the PPP model is a one-off and easy opportunity to win a stream of government-backed revenue lasting up to 30 years. It is no surprise, therefore, that many regions' officials and businesspeople with close ties to the regional and local authorities tried to ensure that a project was implemented through the PPP mechanism (often by way of direct negotiations and without any competition), rather than via the traditional procurement process under the Public Procurement Law that requires an open tender. Many of the PPP projects implemented in the regions during Stage Four, therefore, are associated with corruption-for example, the infamous corruption case in Mangistau region in 2019, where the region's deputy head has been sentenced to ten years in prison for "protecting" a foreign investor who proposed to construct an ice-rink stadium in Aktau by making use of the PPP model (Kapital [19]) .

By the end of 2018, it became increasingly evident that PPP development requires significant adjustment and that the current PPP policy that enables exponential growth of the regional-level PPPs may wipe out Kazakhstan's state budget and seriously undermine the economy. The General Prosecutor's Office, the Ministry of Finance, and the National Chamber of Entrepreneurs (Atameken) each conducted their own investigations of the PPP deployment practice in the country and publicly confirmed numerous cases of fake PPPs, lack of transparency, and misuse of the PPP mechanism by the regional and local officials, including for corruption reasons (Akorda [20]) . To address these issues, in May 2019, Kazakhstan's government announced a new PPP policy with 
project quality as a priority (in contrast to Stage Four policy, in which quantity of PPP projects was an unofficial priority).

Implementing the newly adopted PPP policy, the Ministry of the National Economy established a categorisation of all future PPP projects depending on the required compensation from the state budget: (i) category 1 projects require compensation of all expenses from the state budget (i.e. the "availability payment" PPP model), (ii) category 2 projects require compensation of the operating expenses only, and (iii) category 3 projects do not require any compensation from the state budget (i.e. the "users pay" model). Since 2019, the new PPP policy in Kazakhstan focuses, therefore, on giving preference to the "users pay" model for the projects (i.e. category 3) over the projects that require any financial commitment from the public sector partner (i.e. categories 1 and 2). To enshrine this new PPP policy in legislation, the Ministry of the National Economy also prepared a draft concept of law that, amongst other changes, would make the 2006 Concession Law applicable only to category 1 and category 2 projects (i.e. all large infrastructure projects that need government financial support would have to be implemented as concessions). The draft proposed that the 2015 PPP Law would be applicable only to category 3 projects that do not require any financial support from the public sector partner.

\section{Policy Goals at This Stage}

In addition to the new PPP policy goal of quality instead of quantity, the PPP Centre put forward an idea to use a new concept initiated by the United Nations Economic Commission for Europe (UNECE) called "People First PPPs" for development of the regional and local infrastructure projects in Kazakhstan. The main objective of this approach is to link PPP activities with public needs and involve domestic investors in providing public services and cultural activities (Rivadeneira and Garin [14]). In other words, it means that the People First PPPs approach requires that interests and needs of the local population be prioritised before the interests of the government (including political and national interests) and business (i.e. interest of the private firms to make profit). To put the People First PPPs concept in practice, the Ministry of the National Economy even introduced certain changes in its by-laws in December 2019 to ensure citizen engagement and improved budget management. At the regional and local levels, the approval for projects in the PPP form will be granted only to those projects that increase access of the local population, especially socially and economically vulnerable people, to essential services, or projects that promote social justice and increase the volume of public services.

\section{Assessment}

It remains to be seen whether a new PPP policy will be successful. However, it is already clear that this new policy has not been well developed. Neither the PPP Centre nor the government offered a clear understanding of what should be viewed as qu ality projects, as it seems that so far the only criterion for quality is the absence of requests for any financial support from the public sector partner. As for the People First PPP concept, it is likely to be just a declaration because its whole idea is self-contradictory. The PPP concept would secure the balance of interests of the government and business, and not the priority of interests of the local population, which would be a legitimate goal of certain socially oriented projects, rather than PPPs. Furthermore, the People First PPP concept would not offer sufficient help in solving the problems with PPP development encountered in Kazakhstan to date. The most tangible effect of the new PPP policy is that the number of executed PPP agreements in 2019 decreased by more than half compared to 2018 .

\section{Implications for Further Policy Development}

There are concerns about whether the PPP Centre, which acts as a think tank for partnership promotion in Kazakhstan, proposed a proper new PPP strategy. The centre's official position is that Kazakhstan as a developing country does not need and cannot afford new large-scale infrastructure projects by means of PPP and, therefore, the strategy should be to implement small-scale and service-type (i.e. without capital investment) PPPs, such as kindergartens, public toilets, and clinics that do not require any financial support from the government (Yeshimova [21]) . The centre's approach to PPP policy development appears rather narrow and is likely to jeopardise the attraction of foreign investment to the PPP schemes in Kazakhstan for a much-needed upgrade of, inter alia, the utilities and energy sector infrastructure.

\section{Conclusion}

Kazakhstan's substantial progress with developing PPPs and their enabling environment lags behind Russia only in the Eurasian Economic Union (Eurasian Economic Commission [22]). 
However, there is still much room for improvement. As a financing mechanism, PPPs, if properly used, can be a useful tool for the government to not only attract private sector funds for upgrading its public infrastructure, but also to address corruption problems in public procurement and provide an effective legal framework for the ongoing privatisation of state-owned assets (e.g. by way of passing state-owned assets first under trust management of a private partner with a right to buy out a PPP facility at the end of the contract term).

In particular, Kazakhstan should tap into the huge potential of participating in China's One Belt and One Road Initiative by promoting PPP best practice to ensure high quality at lower costs. For example, the light rail system project in the city of Nur-Sultan, which was not structured as a PPP but rather with financing and investment coming from China, could have been implemented using the open tender in the PPP legal framework in the first place. The failure to structure this project as a PPP from the outset is now causing this project to fail and could become an embarrassment for the government, as well as lead to a wasteful use of the budget funds.

As the coronavirus outbreak spreads across the globe, it is likely that many existing PPP projects in Kazakhstan will experience considerable revenue generation challenges. At the same time, the need to attract private investment in Kazakhstan's healthcare system, agriculture, utilities, and other public infrastructure becomes even more acute. The time has come, therefore, to revisit the existing PPP policy. One option is to focus on the deployment of a larger number of adequately designed infrastructure PPPs at the national level with involvement of the IFIs and foreign investors, while the number of local-level small-scale service-type PPPs should decrease.

\section{References:}

1. European Bank for Reconstruction and Development (EBRD). (2018). 2017/2018 Review: Kazakhstan. Available via https://ppp-ebrd.com/review. php?country=Kazakhstan. Accessed 4 April 2020.

2. Rivadeneira, A. M. R., \& Garin, J. (2019) Public private partnerships review of Kazakhstan. OECD Journal of Budgeting, 2, 3-86. Available via https://doi.org/10.1787/f7696c94-en. Accessed 4 April 2020.

3. Mouraviev, N., Kakabadse, N., \& Robinson, I. (2012). Concessionary nature of public-private partnerships in Russia and Kazakhstan: A critical review. International Journal of Public Administration, 35(6), 410-420.

4. Newsworld. (2020, March 24). SK E\&C strikes financial contract with investors to finance Almaty Ring Road. Available via http://www.newsworld.co.kr/detail.htm?no=6426. Accessed 4 April 2020.

5. Kazakhstan Public-Private Partnership Centre. (2020). PPP Centre. Available via https://kzppp. kz/projects. Accessed 23 April 2020.

6. Matayev, T. (2014). Concessions in the Republic of Kazakhstan [in Russian]. Vestnik Finansovogo Universiteta, 3, 105-113. Available via https://cyberleninka.ru/article/n/kontsessii-v-respublike-kazahstan. Accessed 4 April 2020.

7. ADB. (2017). Public-private partnership monitor. Available via http://dx.doi.org/10.22617/ TCS179134-2. Accessed 4 April 2020.

8. Mouraviev, N., \& Kakabadse, N. K. (2017). Public-private partnerships: Policy and governance challenges facing Kazakhstan and Russia. London: Palgrave Macmillan.

9. UNECE PPP Assessment Report. (2013). Green PPPs in Kazakhstan. The United Nations Economic Commission for Europe. Available via https://www.unece.org/fileadmin/DAM/ceci/documents/UNDA_project/PPP_Readiness_Assessment_Kazakhstan.pdf. Accessed 26 April 2020.

10. Yescombe, E. R., \& Farquharson, E. (2018). Public-private partnerships for infrastructure: Principles of policy and finance. Oxford: Butterworth- Heinemann.

11. Tuktarov, Y., \& Dubinchina, S. V. (Eds.). (2016). A concession agreement: Its legal nature, scope of application, and execution [in Russian]. Moscow: Statut.

12. Beisembinova, A. (2011). Regulation of investment activity on the basis of public-private partnership [in Russian]. Vestnik KazEU. Available via https://articlekz.com/article/13982. Accessed 25 April 2020. 
13. Law of the Republic of Kazakhstan. (2015). The Law on Public-private partnership [in Russian]. Law No 379-V of 31 October 2015. Available via http://adilet.zan.kz/eng/docs/Z1500000379. Accessed 26 April 2020.

14. Rivadeneira, A. M. R., \& Garin, J. (2019) Public private partnerships review of Kazakhstan. OECD Journal of Budgeting, 2, 3-86. Available via https://doi.org/10.1787/f7696c94-en. Accessed 4 April 2020.

15. SZP. (2019). Court cases about dispute resolution in the PPP projects in Kazakhstan [in Russian]. Available via https://szp.kz/custom/wysiwyg/image/file/20191127/20191127115011_65 888.pdf. Accessed 4 April 2020.

16. Atameken. (2019). PPP project financing: Issues and suggestions to address them. A presentation. Available via https://forum.kzppp.kz/uploads/calendar/14/file3/3.\%20Yakupbayeva\%20 Yulia.pdf?cache=1573484612. Accessed 4 April 2020.

17. Chikanayev, S. (2017). A public-private partnership agreement as a new kind of an agreement in Kazakhstan's civil law and the problems of its categorisation [in Russian]. Kaspiyskiy Obschestvenniy Universitet, Research publications series Adilet, No 3. Available via https:// online.zakon.kz/Document/?doc_id=39697495\#pos=36;70. Accessed 26 April 2020.

18. Chikanayev, S. (2015). Kazakhstan. In B. Werneck \& M. Saadi (Eds.), The public-private partnership law review (pp. 144-165). London: Law Business Research Ltd.

19. Kapital. (2019, August 27). Ex-deputy head of Mangistau region was sentenced to 10 years in prison [in Russian]. Available via https://kapital.kz/gosudarstvo/80767/eks-zamakima-mangistauskoy-oblasti-poluchil-10-let-lisheniyasvobody. html. Accessed 25 April 2020.

20. Akorda. (2019, November 26). Secretary of State conducted a meeting of the President's Commission on fighting corruption [in Russian]. News item on the official website of the President of the Republic of Kazakhstan. Available via https://www.akorda.kz/ru/secretary_of_state/ secretary_of_state_news/gosudarstvennyi-sekretar-provel-zasedanie-komissii-pri-prezidenterespubliki-kazahstan-po-voprosam-protivodeistviya-korrupcii?q=\%D0\%93\%D0\%A7\%D0\%9F.Accessed 26 April 2020.

21. Yeshimova, D. (2019). Interview of the first Vice Chairman of Kazakhstan's PPP Centre to Khabar TV channel [in Russian]. Available via https://www.youtube.com/ watch?v=BMaOSOZRvUM. Accessed 4 April 2020.

22. Eurasian Economic Commission. (2018). PPP in countries of the Eurasian Economic Union. Practical guide for investors [in Russian]. Available via http://www.eurasiancommission.org/ ru/act/finpol/dobd/ppp/Documents/Evrazes_Book-2018_A4.pdf. Accessed 26 April 2020. 